\title{
Erratum to: An interstitial deletion at 8q23.1-q24.12 associated with Langer-Giedion syndrome/ Trichorhinophalangeal syndrome (TRPS) type II and Cornelia de Lange syndrome 4
}

Nikoletta Selenti, Maria Tzetis, Maria Braoudaki, Krinio Giannikou, Sofia Kitsiou-Tzeli and Helen Fryssira

The original version of this article [1] unfortunately contained a mistake. In the author list, the surname of author Krinio Giannikou was incorrectly spelled. The original article has now been updated with the correct spelling.

Received: 21 August 2015 Accepted: 21 August 2015

Published online: 30 September 2015

\section{Reference}

1. Selenti N, Tzetis M, Braoudaki M, Gianikou K, Kitsiou-Tzeli S, Fryssira H.

An interstitial deletion at 8q23.1-q24.12 associated with LangerGiedion syndrome/ Trichorhinophalangeal syndrome (TRPS) type II. and Cornelia de Lange syndrome 4. Molecular Cytogenetics 2015, 8:64 doi:10.1186/s13039-015-0169-9.

\footnotetext{
* Correspondence: nikoletta_selenti@hotmail.com

Department of Medical Genetics, Aghia Sophia Childrens' Hospital, Athens University, School of Medicine, Thivon and Levadeias, 11527, Goudi, Athens,
} Greece

Submit your next manuscript to BioMed Central and take full advantage of:

- Convenient online submission

- Thorough peer review

- No space constraints or color figure charges

- Immediate publication on acceptance

- Inclusion in PubMed, CAS, Scopus and Google Scholar

- Research which is freely available for redistribution

Submit your manuscript at www.biomedcentral.com/submit 